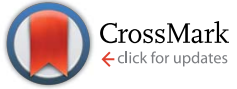

Cite this: RSC Adv., 2016, 6, 38332

Received 24th March 2016 Accepted 10th April 2016

DOI: 10.1039/c6ra07701c

www.rsc.org/advances

\section{Hydrolytic behaviour of mono- and dithiolato- bridged dinuclear arene ruthenium complexes and their interactions with biological ligands $\uparrow$}

\author{
David Stíbal, ${ }^{a}$ Lennart Geiser, ${ }^{b}$ Georg Süss-Fink ${ }^{a}$ and Julien Furrer ${ }^{\star b}$
}

The hydrolysis and the reactivity of two dinuclear $p$-cymene ruthenium monothiolato complexes, $\left[\left(\eta^{6}-p\right.\right.$ $\left.\left.\mathrm{MeC}_{6} \mathrm{H}_{4} \mathrm{Pr}^{\mathrm{i}}\right)_{2} \mathrm{Ru}_{2} \mathrm{Cl}_{2}(\mu-\mathrm{Cl})\left(\mu-\mathrm{S}-m-9-\mathrm{B}_{10} \mathrm{C}_{2} \mathrm{H}_{11}\right)\right]$ (1) and $\left[\left(\eta^{6}-p-\mathrm{MeC}_{6} \mathrm{H}_{4} \mathrm{Pr}^{\mathrm{i}}\right)_{2} \mathrm{Ru}_{2} \mathrm{Cl}_{2}(\mu-\mathrm{Cl})\left(\mu-\mathrm{SCH}_{2}-p-\mathrm{C}_{6} \mathrm{H}_{4}-\right.\right.$ $\left.\left.\mathrm{NO}_{2}\right)\right](2)$, and of two dinuclear $p$-cymene ruthenium dithiolato complexes, $\left[\left(\eta^{6}-p-\mathrm{MeC}_{6} \mathrm{H}_{4} \mathrm{Pr}^{\mathrm{i}}\right)_{2} \mathrm{Ru}_{2}(\mu-\right.$ $\left.\left.\mathrm{SCH}_{2} \mathrm{CH}_{2} \mathrm{Ph}\right)_{2} \mathrm{Cl}_{2}\right]$ (3) and $\left[\left(\eta^{6}-p-\mathrm{MeC}_{6} \mathrm{H}_{4} \mathrm{Pr}^{\mathrm{i}}\right)_{2} \mathrm{Ru}_{2}\left(\mathrm{SCH}_{2} \mathrm{C}_{6} \mathrm{H}_{4}-p-\mathrm{OMe}\right)_{2} \mathrm{Cl}_{2}\right]$ (4) towards amino acids, nucleotides, and a single-stranded DNA dodecamer were studied using NMR and mass spectrometry. In aqueous solutions at $37^{\circ} \mathrm{C}$, the monothiolato complexes 1 and 2 undergo rapid hydrolysis, irrespective of the $\mathrm{pH}$ value, the predominant species in $\mathrm{D}_{2} \mathrm{O} /$ acetone- $\mathrm{d}_{6}$ solution at equilibrium being the neutral hydroxo complexes $\left[\left(\eta^{6}-p-\mathrm{MeC}_{6} \mathrm{H}_{4} \mathrm{Pr}^{\mathrm{i}}\right)_{2} \mathrm{Ru}_{2}(\mathrm{OD})_{2}(\mu-\mathrm{OD})(\mu-\mathrm{SR})\right]$. The dithiolato complexes 3 and 4 are stable in water under acidic conditions, but undergo slow hydrolysis under neutral and basic conditions. In both cases, the cationic hydroxo complexes $\left[\left(\eta^{6}-p-M_{-} C_{6} \mathrm{H}_{4} \mathrm{Pr}^{i}\right)_{2} \mathrm{Ru}_{2}(\mathrm{OD})\left(\mathrm{CD}_{3} \mathrm{CN}\right)(\mu-\mathrm{SR})_{2}\right]^{+}$are the only species observed in $\mathrm{D}_{2} \mathrm{O} / \mathrm{CD}_{3} \mathrm{CN}$ at equilibrium. Surprisingly, no adducts are observed upon addition of an excess of L-methionine or L-histidine to the aqueous solutions of the complexes. Upon addition of an excess of L-cysteine, on the other hand, 1 and 2 form the unusual cationic trithiolato complexes $\left[\left(\eta^{6}-p\right.\right.$ $\left.\left.\mathrm{MeC}_{6} \mathrm{H}_{4} \mathrm{Pr}^{\mathrm{i}}\right)_{2} \mathrm{Ru}_{2}\left\{\mu-\mathrm{SCH}_{2} \mathrm{CH}\left(\mathrm{NH}_{2}\right) \mathrm{COOH}\right\}_{2}(\mu-\mathrm{SR})\right]^{+}$containing two bridging cysteinato ligands, while 3 and 4 yield cationic trithiolato complexes $\left[\left(\eta^{6}-p-\mathrm{MeC}_{6} \mathrm{H}_{4} \mathrm{Pr}^{i}\right)_{2} \mathrm{Ru}_{2}\left[\mu-\mathrm{SCH}_{2} \mathrm{CH}\left(\mathrm{NH}_{2}\right) \mathrm{COOH}\right](\mu-\mathrm{SR})_{2}\right]^{+}$containing one bridging cysteinato ligand. A representative of cationic trithiolato complexes containing a cysteinato bridge of this type, $\left[\left(\eta^{6}-p-\mathrm{MeC}_{6} \mathrm{H}_{4} \mathrm{Pr}^{i}\right)_{2} \mathrm{Ru}_{2}\left[\mu-\mathrm{SCH} \mathrm{CH}_{2} \mathrm{CH}\left(\mathrm{NH}_{2}\right) \mathrm{COOH}\right]\left(\mu-\mathrm{SCH}_{2}-p-\mathrm{C}_{6} \mathrm{H}_{4}-\mathrm{Bu}^{t}\right)_{2}\right]^{+}$(6) could be synthesised from the dithiolato complex $\left[\left(\eta^{6}-p-\mathrm{MeC}_{6} \mathrm{H}_{4} \mathrm{Pr}^{i}\right)_{2} \mathrm{Ru}_{2}\left(\mathrm{SCH}_{2} \mathrm{C}_{6} \mathrm{H}_{4}-p-\mathrm{Bu}^{t}\right)_{2} \mathrm{Cl}_{2}\right]$ (5), isolated as the tetrafluoroborate salt and fully characterised. Moreover, the mono- and dithiolato complexes 1-4 are inert toward nucleotides and DNA, suggesting that DNA is not a target of cytotoxic thiolato-bridged arene ruthenium complexes. In contrast to the trithiolato complexes, monothiolato and dithiolato complexes hydrolyse and react with L-cysteine. These results may have important implications for the mode of action of thiolato-bridged dinuclear arene ruthenium drug candidates, and suggest that their modes of action are different to those of other arene ruthenium complexes.

\section{Introduction}

Ever since the serendipitous discovery of the anticancer properties of cisplatin in $1965^{1}$ and its clinical use in $1978,{ }^{2}$ the research on platinum cytostatics has flourished. A plethora of analogous square-planar platinum(II) and octahedral platinum(Iv) complexes was synthesised and studied in order to find more selective and less toxic alternatives. ${ }^{3}$ Despite immense efforts, only two additional platinum complexes were approved for global use in the clinic so far: the second-generation drug carboplatin was approved by the FDA in 1989 and the third-

${ }^{a}$ Institut de Chimie, Université de Neuchâtel, CH-2000 Neuchâtel, Switzerland ${ }^{b}$ Departement für Chemie und Biochemie, Universität Bern, CH-3012 Bern, Switzerland. E-mail: julien.furrer@dcb.unibe.ch; Fax: +41316314887

$\dagger$ Electronic supplementary information (ESI) available. See DOI: 10.1039/c6ra07701c generation oxaliplatin in 2002. ${ }^{4}$ Unfortunately, none of the three agents possess very high selectivity towards cancerous cells; their therapeutic application therefore causes severe side effects such as nephrotoxicity, ${ }^{5-7}$ neurotoxicity ${ }^{\mathbf{8} 9}$ and nausea. ${ }^{\mathbf{8 , 1 0}}$ In order to overcome these side-effects, part of the research on metallodrugs has shifted from platinum to ruthenium-based anticancer agents. Ruthenium compounds have in general lower systemic toxicity than platinum drugs, they can access a wide range of oxidation states under physiological conditions and have a very similar ligand exchange rate as platinum complexes. ${ }^{11}$ The field of anticancer ruthenium compounds was pioneered by Alessio, Sava and Keppler, who developed ruthenium(III) imidazole and indazole complexes, the imidazolium or indazolium salts of which (termed NAMI-A and KP1019, respectively) have already entered clinical trials. ${ }^{\mathbf{1 2 - 1 5}}$ The sodium analogue of KP1019, termed NKP-1339, is now on the edge of clinical application. ${ }^{\mathbf{1 6}}$ 
In 1992, Tocher and co-workers have observed a cytotoxicity enhancement by coordinating the anticancer agent metronidazole [1- $\beta$-(hydroxyethyl)-2-methyl-5-nitro-imidazole] to a benzene ruthenium dichlorido fragment. ${ }^{17}$ Subsequently, it became obvious that water-soluble arene ruthenium complexes are in general cytotoxic, since they seem to have the right balance between lipophilicity and hydrophilicity, essential for cellular uptake. ${ }^{18}$ The first prototype arene ruthenium(II) complexes evaluated for anticancer properties in 2001 were $\left[\left(\eta^{6}-p-\mathrm{MeC}_{6} \mathrm{H}_{4} \mathrm{Pr}^{\mathrm{i}}\right)\right.$ $\mathrm{Ru}(P$-pta $\left.) \mathrm{Cl}_{2}\right]$ (pta = 1,3,5-triaza-7-phosphaadamantane), termed RAPTA-C, from Dyson's laboratory ${ }^{19}$ and the RAED family of compounds $\left[\left(\eta^{6}-\mathrm{C}_{6} \mathrm{H}_{5} \mathrm{Ph}\right) \mathrm{Ru}-(N, N-\mathrm{en}) \mathrm{Cl}\right]^{+}$as hexafluorophosphate or chloride salt from Sadler's laboratory. ${ }^{20}$ Importantly, although RAPTA-C only exhibits a low activity in vitro, it is very active in vivo, where it inhibits lung metastases in CBA mice. ${ }^{21}$ Therefore, RAPTA-C can be considered as an antimetastatic agent like NAMIA. ${ }^{21,22}$ RAED compounds are highly cytotoxic to a range of cancer cell lines, ${ }^{23}$ including cisplatin-resistant cell lines. An in vivo study established that RM175, $\left[\left(\eta^{6}-\mathrm{C}_{6} \mathrm{H}_{5} \mathrm{Ph}\right) \mathrm{Ru}(N, N-e n) \mathrm{Cl}\right] \mathrm{PF}_{6}$, is active against MCa mammary carcinoma and causes metastasis reduction. ${ }^{24}$ In addition to these two prototype compounds, a plethora of organometallic ruthenium(II) compounds have been prepared and their cytotoxicity to cancer cells examined. ${ }^{25-33}$

In recent years, we have synthesised several series of dinuclear arene ruthenium thiolato-bridged complexes of the general formula $\left[\left(\eta^{6} \text {-arene }\right)_{2} \mathrm{Ru}_{2}(\mu \text {-SR })_{3}\right] \mathrm{Cl}$ that are highly cytotoxic against ovarian cancer cell lines $\mathrm{A} 2780$ and $\mathrm{A} 2780$ cisR, the most active derivative $\left[\left(\eta^{6}-p-\mathrm{MeC}_{6} \mathrm{H}_{4} \mathrm{Pr}^{\mathrm{i}}\right)_{2} \mathrm{Ru}_{2}\left(\mu-\mathrm{S}-p-\mathrm{C}_{6} \mathrm{H}_{4} \mathrm{Bu}^{t}\right)_{3}\right] \mathrm{Cl}$ (diruthenium-1) having an $\mathrm{IC}_{50}$ value of $30 \mathrm{nM}$ to both cell lines. ${ }^{34-39}$ To the best of our knowledge, diruthenium-1 is the most cytotoxic arene ruthenium compound reported to date. A recent in vivo study has demonstrated that dinuclear arene ruthenium thiolato-bridged complexes have the potential to become anticancer chemotherapy agents, since diruthenium-1 significantly prolongs the survival of tumour-bearing mice. ${ }^{40}$

By varying the synthetic procedure, we succeeded in isolating neutral dithiolato complexes of the type $\left[\left(\eta^{6}-p-\mathrm{MeC}_{6} \mathrm{H}_{4} \mathrm{Pr}^{\mathrm{i}}\right)_{2}\right.$ $\left.\mathrm{Ru}_{2}(\mu-\mathrm{SR})_{2} \mathrm{Cl}_{2}\right]^{41}$ and subsequently also monothiolato complexes of the general formula $\left[\left(\eta^{6}-p-\mathrm{MeC}_{6} \mathrm{H}_{4} \mathrm{Pr}^{\mathrm{i}}\right)_{2} \mathrm{Ru}_{2} \mathrm{Cl}_{2}(\mu-\mathrm{Cl})(\mu-\mathrm{SR})\right]{ }^{42}$ intermediates in the formation of the cationic trithiolato complexes, thus opening new avenues for the fine-tuning the properties of dinuclear thiolato-bridged arene ruthenium complexes (Scheme 1). ${ }^{43}$

Interestingly, the mono- and dithiolato analogues are systematically at least one order of magnitude less cytotoxic than their trithiolato counterparts. ${ }^{36,38,39}$ The stability and reactivity studies of some trithiolato complexes with various amino acids, peptides, nucleotides and DNA revealed that the complexes are very stable in physiological conditions as well as under acidic and basic conditions and that they are particularly inert towards substitution. Only the sulphur-containing biomolecules cysteine (Cys) and the tripeptide glutathione (GSH) interact with the complexes. Unexpectedly, no adducts were identified, but Cys and GSH undergo a catalytic oxidation in the presence of the trithiolato complexes, forming cystine and GSSG. ${ }^{35}$ Such a mode of action has already been proposed for arene ruthenium azopyridine iodo complexes, which are surprisingly cytotoxic despite their inertness

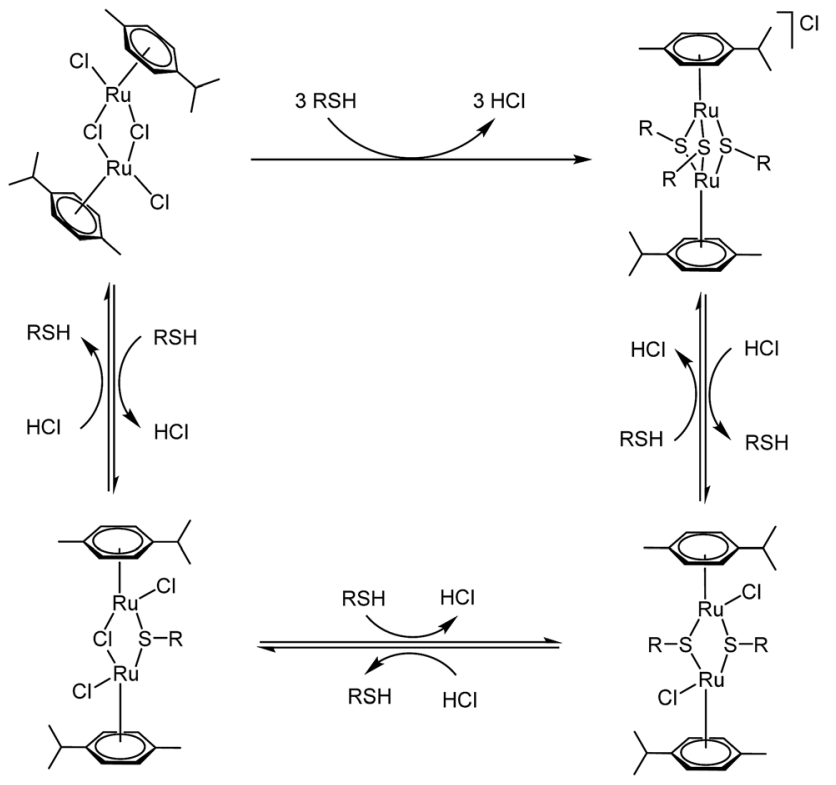

Scheme 1 Stepwise synthesis of thiolato-bridged arene ruthenium complexes. ${ }^{42}$

to ligand substitution. ${ }^{44}$ Although a decrease in the glutathione levels with increasing concentration of diruthenium-1 was observed in vitro and in vivo, ${ }^{\mathbf{4 0}}$ no direct correlation between their cytotoxicity and catalytic activity for the oxidation of glutathione was found..$^{36,38,39}$ We therefore assume that other mechanisms are mainly responsible for the high in vitro cytotoxicity of the trithiolato complexes.

In an effort to rationalise the relationship between reactivity and the in vitro cytotoxicity of thiolato-bridged arene ruthenium complexes, we set out to investigate the hydrolysis of two monothiolato complexes $\mathbf{1}$ and $\mathbf{2}$ and two dithiolato complexes

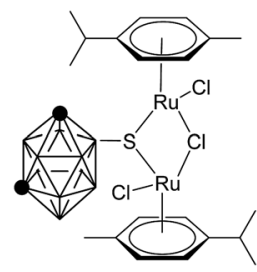

1

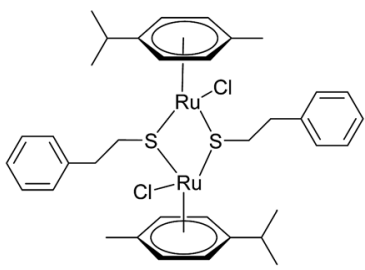

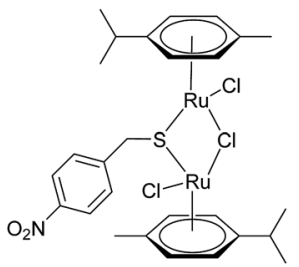

2

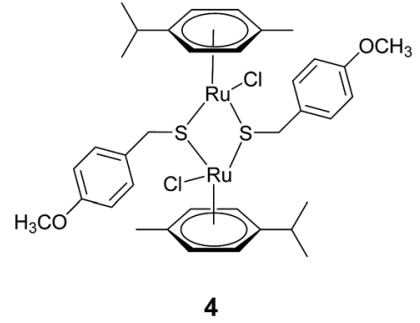

Fig. 1 Structures of complexes 1-4, the symbols in the formula of 1 represent $\mathrm{CH}$ groups of the carborane moiety. 
3 and 4 (Fig. 1) as well as their interactions with selected amino acids, nucleotides and a single-stranded DNA dodecamer.

\section{Results and discussion}

\subsection{Stability of the monothiolato complexes 1 and 2 in aqueous solution}

Fig. 2 shows the $1 \mathrm{D}{ }^{1} \mathrm{H}-\mathrm{NMR}$ spectra of 1 dissolved in $\mathrm{a}_{2} \mathrm{O} /$ acetone- $\mathrm{d}_{6}$ mixture (ratio $7: 3$ ) at $\mathrm{pD} 7$, recorded at $37{ }^{\circ} \mathrm{C}$ between $5 \mathrm{~min}$ and $24 \mathrm{~h}$. Additional resonances appeared immediately after sample preparation, indicating rapid hydrolysis, and equilibrium is reached after about $1 \mathrm{~h}$. Analysis of the doublets for the $p$-cymene ring protons suggests that three species are present in solution. One with resonances at $\delta=5.53$ and $5.80 \mathrm{ppm}$ is identified as $\mathbf{1}$, and a second one with four resonances at $\delta=5.11,5.27,5.62$ and $5.72 \mathrm{ppm}$ is attributed to a species that underwent chloro/aqua exchange. This species, which is the most abundant one present in solution after $1 \mathrm{~h}$, is assumed to be the neutral hydroxo complex $\left[\left(\eta^{6}-p-\mathrm{MeC}_{6} \mathrm{H}_{4}\right.\right.$ $\left.\left.\operatorname{Pr}^{\mathrm{i}}\right)_{2} \mathrm{Ru}_{2}(\mathrm{OD})_{2}(\mu-\mathrm{OD})\left(\mu-\mathrm{S}-m-9-\mathrm{B}_{10} \mathrm{C}_{2} \mathrm{H}_{11}\right)\right]$ (Scheme S1 $\left.\dagger\right)$. The high symmetrical nature of this fully hydrolysed complex is supported by the single ${ }^{1} \mathrm{H}$-NMR resonances observed for the $p$-cymene protons in the high field region of the ${ }^{1} \mathrm{H}-\mathrm{NMR}$ spectrum (Fig. S1 $\dagger$ ). For the hypothetical mixed hydroxo-chloro complex $\left[\left(\eta^{6}-p-\mathrm{MeC}_{6} \mathrm{H}_{4} \mathrm{Pr}^{\mathrm{i}}\right)_{2} \mathrm{Ru}_{2}(\mathrm{OD})(\mathrm{Cl})(\mu-\mathrm{OD})\left(\mu-\mathrm{S}-m-9-\mathrm{B}_{10} \mathrm{C}_{2} \mathrm{H}_{11}\right)\right]$, two sets of resonances would be observed for these protons. The fact that four resonances are observed for the $p$-cymene ring protons is not

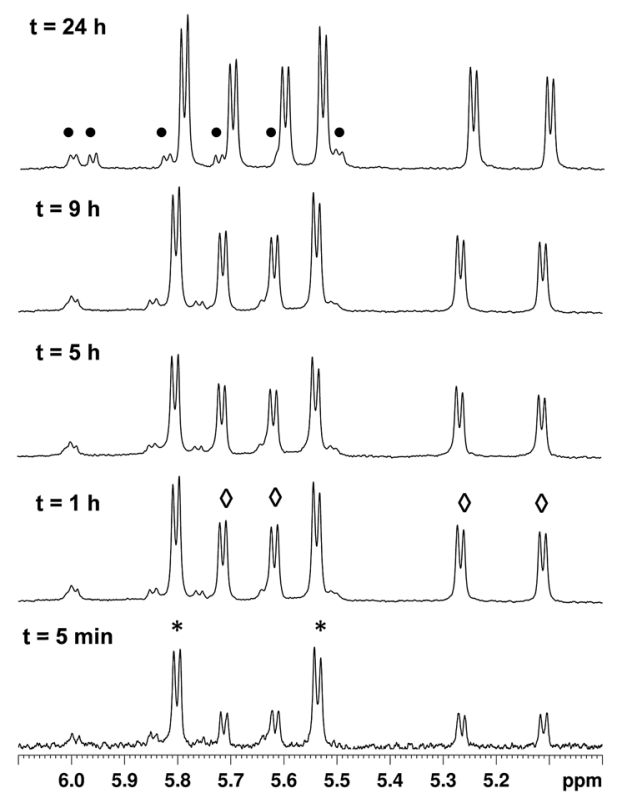

Fig. 2 The $p$-cymene ring proton region of the ${ }^{1} \mathrm{H}$ NMR spectrum of $\left[\left(\eta^{6}-p-\mathrm{MeC}_{6} \mathrm{H}_{4} \mathrm{Pr}^{i}\right)_{2} \mathrm{Ru}_{2} \mathrm{Cl}_{2}(\mu-\mathrm{Cl})\left(\mu-\mathrm{S}-m-9-\mathrm{B}_{10} \mathrm{C}_{2} \mathrm{H}_{11}\right)\right]$ (1) dissolved in $\mathrm{D}_{2} \mathrm{O} /$ acetone- $\mathrm{d}_{6}$ (ratio $7: 3$ ), recorded between $t=5 \mathrm{~min}$ and $t=24 \mathrm{~h}$ at $37^{\circ} \mathrm{C}$ and at $\mathrm{pD} 7$. The labels correspond to $p$-cymene ligands in different species present in solution. The species labeled * corresponds to complex 1 , the species labeled $\diamond$ is presumably the fully hydrolysed species $\left[\left(\eta^{6}-p-\mathrm{MeC}_{6} \mathrm{H}_{4} \mathrm{Pr}^{i}\right)_{2} \mathrm{Ru}_{2}(\mathrm{OD})_{2}(\mu-\mathrm{OD})(\mu-\mathrm{S}-m-9-\right.$ $\mathrm{B}_{10} \mathrm{C}_{2} \mathrm{H}_{11}$ )], while the species labeled with has not been further characterised. surprising. The molecular structures of several dinuclear trithiolato-bridged ruthenium complexes, which are apparently highly symmetrical, show that the two ruthenium atoms adopt a pseudo-octahedral geometry. ${ }^{36}$ Consequently, four doublets caused by the eight aromatic protons of the two $p$-cymene rings are often present in the region between 4.90 and $6.00 \mathrm{ppm} .{ }^{39} \mathrm{~A}$ third, minor species with resonances at $\delta=5.50,5.62,5.73,5.82$, 5.96 and $6.00 \mathrm{ppm}$ is also present in the mixture immediately after sample preparation. A full characterisation was not attempted due to its very low concentration. However, since six $p$ cymene ring proton resonances and four methyl resonances between 1.10 and $1.32 \mathrm{ppm}$ in the high field region of the ${ }^{1} \mathrm{H}-\mathrm{NMR}$ spectrum (Fig. S1 $\dagger$ ) are observed for this species, it may be assumed that it is a mixed hydroxo-chloro complex, for instance $\left[\left(\eta^{6}-p-\mathrm{MeC}_{6} \mathrm{H}_{4} \mathrm{Pr}^{\mathrm{i}}\right)_{2} \mathrm{Ru}_{2}(\mathrm{OD})(\mathrm{Cl})(\mu-\mathrm{OD})\left(\mu-\mathrm{S}-m-9-\mathrm{B}_{10} \mathrm{C}_{2} \mathrm{H}_{11}\right)\right]$.

Similar results are obtained for 2 , however, the hydrolysis is significantly faster, and the equilibrium is already reached after 5 min since no further changes in the NMR spectra are noticed subsequently (Fig. S2 $\dagger$ ). In order to study the suppression of hydrolysis by chloride ions, the same series of NMR spectra of both complexes were recorded in $105 \mathrm{mM} \mathrm{NaCl}$ solution. No spectral changes are observed, indicating that aquation is inhibited and that the observed products are indeed hydrolysed species. These results indicate that $\mathbf{1}$ and $\mathbf{2}$, unless metabolised in a different way, e.g. by protein binding, should survive the conditions in the bloodstream and that the hydrolysis could take place inside the cells where the chloride concentration decreases to $c a$. $4 \mathrm{mM}$.

The formation of the hydroxo complexes $\left[\left(\eta^{6}-p-\mathrm{MeC}_{6} \mathrm{H}_{4}-\right.\right.$ $\left.\left.\mathrm{Pr}^{\mathrm{i}}\right)_{2} \mathrm{Ru}_{2}(\mathrm{OH})_{2}(\mu-\mathrm{OH})(\mu-\mathrm{SR})\right]$ by hydrolysis could be supported by ESI-MS measurements. The ESI-MS spectra of 1 and 2 dissolved in aqueous solutions at $\mathrm{pH} 7$ recorded after $24 \mathrm{~h}$ show in each case a single group of peaks centred at $m / z=681.19$ for 1 and at $m / z=674.05$ for 2 , respectively (Fig. S3 \& S4 $\dagger$ ), obtained most likely by loss of a single hydroxo ligand from the fully hydrolysed complexes $\left[\left(\eta^{6}-p-\mathrm{MeC}_{6} \mathrm{H}_{4} \mathrm{Pr}^{\mathrm{i}}\right)_{2} \mathrm{Ru}_{2}(\mathrm{OH})_{2}(\mu-\mathrm{OH})(\mu-\mathrm{SR})\right]$. In addition, there is no evidence for the formation of chlorohydroxo complexes in both ESI-MS spectra. At $\mathrm{pH}=4$, the hydrolysis proceeds much slower (Fig. S5 \& S6†) and the ESI-MS spectra of both complexes recorded after $24 \mathrm{~h}$ show the starting complex $\left[\left(\eta^{6}-p-\mathrm{MeC}_{6} \mathrm{H}_{4} \mathrm{Pr}^{\mathrm{i}}\right)_{2} \mathrm{Ru}_{2} \mathrm{Cl}_{2}(\mu-\mathrm{Cl})(\mu-\mathrm{SR})\right]$, revealed by the group of peaks centred at $m / z=717.12$ for 1 (Fig. S5 $\dagger$ ) and at $m / z$ $=709.1$ for 2 , (Fig. S6 $\dagger$ ), and the monohydroxo complexes $\left[\left(\eta^{6}-p\right.\right.$ $\left.\left.\mathrm{MeC}_{6} \mathrm{H}_{4} \mathrm{Pr}^{\mathrm{i}}\right)_{2} \mathrm{Ru}_{2} \mathrm{Cl}(\mathrm{OH})(\mu-\mathrm{Cl})(\mu-\mathrm{SR})\right]$, revealed by the group of peaks centred at $m / z=699.16$ for 1 and at $m / z=692.01$ for 2 . Interestingly, for 2, a group of peaks centred at $\mathrm{m} / z=842.2$ corresponding to the dithiolato complex $\left[\left(\eta^{6}-p-\mathrm{MeC}_{6} \mathrm{H}_{4} \mathrm{Pr}^{\mathrm{i}}\right)_{2}\right.$ $\left.\mathrm{Ru}_{2} \mathrm{Cl}\left(\mu-\mathrm{SCH}_{2}-p-\mathrm{C}_{6} \mathrm{H}_{4}-\mathrm{NO}_{2}\right)_{2}\right]$ is also visible the ESI-MS spectrum. The formation of a dithiolato complex during hydrolysis is not surprising, since equilibria between the thiolato complexes and the thiol have been evidenced. ${ }^{\mathbf{4 2 , 4 3}}$ The coordinated thiolato bridge can come off as thiol to be replaced by a thiolato bridge derived from another thiol, which leads to a mixture of thiolato complexes. These equilibria are governed mostly by the reactivity of the thiols and to a lesser extent by the choice of the solvent and reaction conditions. ${ }^{42}$ 


\subsection{Stability of the dithiolato complexes 3 and 4 in aqueous} solution

Fig. 3 shows the $1 \mathrm{D}{ }^{1} \mathrm{H}-\mathrm{NMR}$ spectra of 3 dissolved in a mixture $\mathrm{D}_{2} \mathrm{O} / \mathrm{CD}_{3} \mathrm{CN}$ (ratio $7: 3$ ) recorded at $37^{\circ} \mathrm{C}$ and at $\mathrm{pD} 7$, between $5 \mathrm{~min}$ and $24 \mathrm{~h}$. Additional resonances appear immediately, indicating that $\mathbf{3}$ undergoes chloro/aqua exchange. However, contrary to what has been found for the monothiolato complexes $\mathbf{1}$ and 2, the hydrolysis of $\mathbf{3}$ is slow and not complete before $24 \mathrm{~h}$ (Fig. 3). Analysis of the doublets for the $p$-cymene ring protons suggests that at least three species are present in the solution. The species with broad resonances at $\delta=5.41$ and $5.54 \mathrm{ppm}$ is identified as 3 . The main species present after $24 \mathrm{~h}$ with four resonances at $\delta=5.28,5.32,5.34$ and $5.41 \mathrm{ppm}$ is assumed to be the cationic hydroxo-acetonitrile complex $\left[\left(\eta^{6}-p\right.\right.$ $\left.\left.\mathrm{MeC}_{6} \mathrm{H}_{4} \mathrm{Pr}^{\mathrm{i}}\right)_{2} \mathrm{Ru}_{2}(\mathrm{OD})\left(\mathrm{CD}_{3} \mathrm{CN}\right)\left(\mu-\mathrm{S}-\mathrm{C}_{2} \mathrm{H}_{4} \mathrm{Ph}\right)_{2}\right]^{+}$, in which one chlorido ligand is replaced by one hydroxo ligand, while the second one is replaced by a molecule of acetonitrile (Fig. 3, S7 and Scheme $\mathrm{S} 2 \dagger)$. The formation of the cationic hydroxoacetonitrile complex $\left[\left(\eta^{6}-p-\mathrm{MeC}_{6} \mathrm{H}_{4} \mathrm{Pr}^{\mathrm{i}}\right)_{2} \mathrm{Ru}_{2}(\mathrm{OD})\left(\mathrm{CD}_{3} \mathrm{CN}\right)(\mu-\mathrm{S}-\right.$ $\left.\left.\mathrm{C}_{2} \mathrm{H}_{4} \mathrm{Ph}\right)_{2}\right]^{+}$with a lower symmetry is further supported by the two sets of ${ }^{1} \mathrm{H}$-resonances of equal intensity observed for the $p$ -
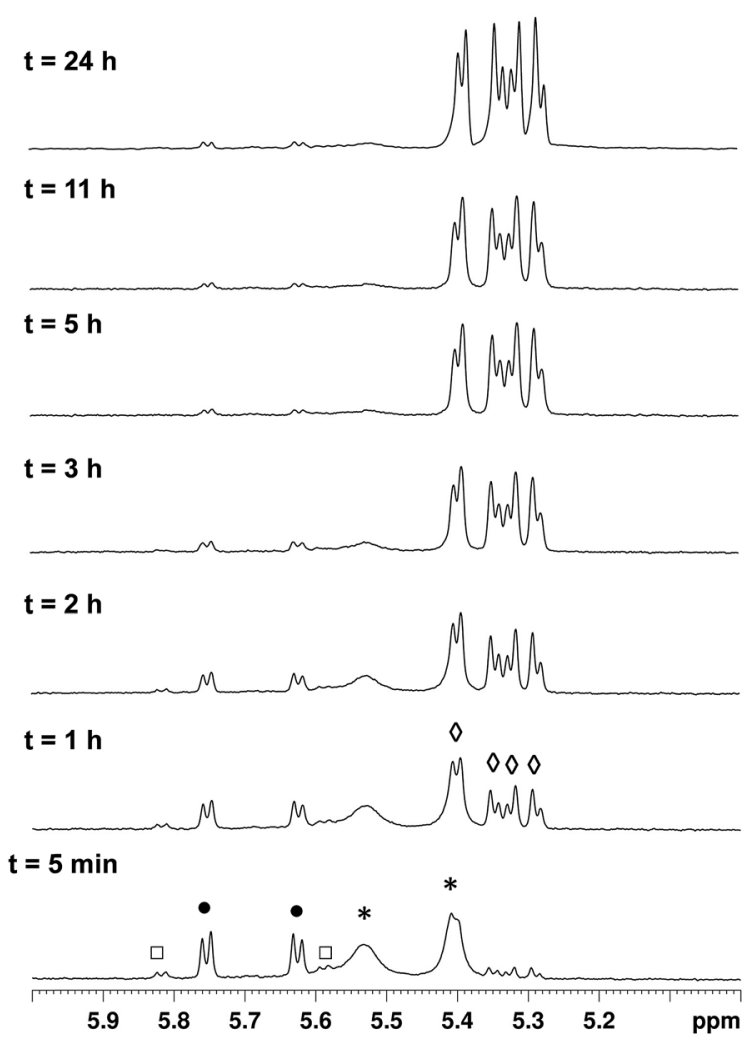

Fig. 3 The $p$-cymene ring proton region of the ${ }^{1} \mathrm{H}$ NMR spectrum of $\left[\left(\eta^{6}-p-\mathrm{MeC}_{6} \mathrm{H}_{4} \mathrm{Pr}^{i}\right)_{2} \mathrm{Ru}_{2}\left(\mu-\mathrm{SC}_{2} \mathrm{H}_{4} \mathrm{Ph}\right)_{2} \mathrm{Cl}_{2}\right]$ (3) dissolved in $\mathrm{D}_{2} \mathrm{O} / \mathrm{CD}_{3} \mathrm{CN}$ (ratio 6:4) recorded between $t=5 \mathrm{~min}$ and $t=24 \mathrm{~h}$ at $37^{\circ} \mathrm{C}$ and at $\mathrm{pD}$ 7. The labels correspond to $p$-cymene ligands in different species present in solution. The species labeled* corresponds to the complex 3 , the species labeled $\diamond$ is assumed to be the hydroxo-acetonitrile complex $\left[\left(\eta^{6}-p-\mathrm{MeC}_{6} \mathrm{H}_{4} \mathrm{Pr}^{i}\right)_{2} \mathrm{Ru}_{2}(\mathrm{OD})\left(\mathrm{CD}_{3} \mathrm{CN}\right)\left(\mu-\mathrm{S}-\mathrm{C}_{2} \mathrm{H}_{4} \mathrm{Ph}\right)_{2}\right]^{+}$, while the species labeled with $\bullet$ and $\square$ have not been further characterised. cymene protons in the high field region of the ${ }^{1} \mathrm{H}-\mathrm{NMR}$ spectrum (Fig. S7†). Two other minor species with resonances at $\delta=$ 5.63 and $5.76 \mathrm{ppm}$ as well as at $\delta=5.59$ and $5.82 \mathrm{ppm}$ can be observed in the mixture immediately after sample preparation, but disappear gradually and are not visible after $5 \mathrm{~h}$. Due to their low concentration and transient character, further characterisation was not attempted. The stability of 3 in $\mathrm{CD}_{3} \mathrm{CN}$ was also evaluated; the NMR spectra show that 3 remains stable for at least 48 hours. Hydrolysis of 3 at $\mathrm{pH} 7$ was supported by the ESI-MS spectrum, which shows a single group of peaks centred at $m / z=808.17$ corresponding to the hydrolysed complex [ $\left(\eta^{6}-p\right.$ $\left.\left.\mathrm{MeC}_{6} \mathrm{H}_{4} \mathrm{Pr}^{\mathrm{i}}\right)_{2} \mathrm{Ru}_{2}(\mathrm{OH})\left(\mathrm{CH}_{3} \mathrm{CN}\right)\left(\mu-\mathrm{S}_{-} \mathrm{C}_{2} \mathrm{H}_{4} \mathrm{Ph}\right)_{2}\right]^{+}$(Fig. S8 $\dagger$ ).

The kinetic experiment was repeated at $\mathrm{pD}=11$ after addition of NaOD. Analysis of the doublets for the $p$-cymene ring protons show that, apart form 3 with broad resonances at $\delta=$ 5.41 and $5.54 \mathrm{ppm}$, the hydroxo-acetonitrile complex $\left[\left(\eta^{6}-p\right.\right.$ $\left.\left.\mathrm{MeC}_{6} \mathrm{H}_{4} \mathrm{Pr}^{\mathrm{i}}\right)_{2} \mathrm{Ru}_{2}(\mathrm{OD})\left(\mathrm{CD}_{3} \mathrm{CN}\right)\left(\mu-\mathrm{S}-\mathrm{C}_{2} \mathrm{H}_{4} \mathrm{Ph}\right)_{2}\right]^{+}$with four resonances at $\delta=5.28,5.32,5.34$ and $5.41 \mathrm{ppm}$ is present in the mixture. Intriguingly, the equilibrium is reached only after $48 \mathrm{~h}$ (Fig. S9†). The same experiment was repeated at pD 2 after addition of DCl. Weak additional resonances can be detected directly after sample preparation, suggesting a rapid hydrolysis or the presence of a second unknown species. However, the equilibrium is reached immediately, as no further changes are visible in the subsequent NMR spectra recorded between $t=5$ min and $t=24 \mathrm{~h}$ (Fig. S10 $\dagger$ ). Analysis of the ${ }^{1} \mathrm{H}$ NMR spectra shows that 3 is the major species present in the mixture.

In the case of $\mathbf{4}$, additional resonances also appeared immediately after sample preparation, indicating rapid hydrolysis, and the equilibrium is reached rapidly after about $2 \mathrm{~h}$ (Fig. 4). The species with two broad resonances at $\delta=5.30$ and $5.38 \mathrm{ppm}$ is identified as 4 . The main species at equilibrium with four resonances at $\delta=4.78,4.83,5.05$ and $5.18 \mathrm{ppm}$ is assumed to be the hydroxo-acetonitrile complex $\left[\left(\eta^{6}-p-\mathrm{MeC}_{6}\right.\right.$ $\left.\left.\mathrm{H}_{4} \mathrm{Pr}^{\mathrm{i}}\right)_{2} \mathrm{Ru}_{2}(\mathrm{OD})\left(\mathrm{CD}_{3} \mathrm{CN}\right)\left(\mu-\mathrm{S}-\mathrm{CH}_{2}-\mathrm{C}_{6} \mathrm{H}_{4}-p-\mathrm{OMe}\right)_{2}\right]^{+}$, similar to that observed with 3 . Two further species with resonances at $\delta=$ 5.20 and $5.49 \mathrm{ppm}$ as well as at $\delta=5.59 \mathrm{ppm}$ are also observed in the mixture immediately after sample preparation, but disappear progressively and are not visible after $2 \mathrm{~h}$. Due to their low concentration and transient character, a further characterisation was not attempted. Hydrolysis of $\mathbf{4}$ at $\mathrm{pH} 7$ was confirmed by the ESI-MS spectrum, which shows a single group of peaks centred at $m / z=840.16$ that matches the hydroxoacetonitrile complex $\left[\left(\eta^{6}-p-\mathrm{MeC}_{6} \mathrm{H}_{4} \mathrm{Pr}^{\mathrm{i}}\right)_{2} \mathrm{Ru}_{2}(\mathrm{OH})\left(\mathrm{CH}_{3} \mathrm{CN}\right)(\mu-\mathrm{S}-\right.$ $\mathrm{CH}_{2}-\mathrm{C}_{6} \mathrm{H}_{4}-p$-OMe $\left.)_{2}\right]^{+}$(Fig. $\mathrm{S} 11 \dagger$ ).

The kinetic experiment was repeated at pD 11 after addition of NaOD. Analysis of the doublets for the $p$-cymene ring protons show that 4 with broad resonances at $\delta=5.28$ and $5.36 \mathrm{ppm}$, and the hydroxo-acetonitrile complex $\left[\left(\eta^{6}-p-\mathrm{MeC}_{6} \mathrm{H}_{4} \mathrm{Pr}^{\mathrm{i}}\right)_{2} \mathrm{Ru}_{2}(-\right.$ $\left.\mathrm{OD})\left(\mathrm{CD}_{3} \mathrm{CN}\right)\left(\mu-\mathrm{S}-\mathrm{CH}_{2}-\mathrm{C}_{6} \mathrm{H}_{4}-p-\mathrm{OMe}\right)_{2}\right]^{+}$with four resonances at $\delta=4.77,4.82,5.06$ and $5.19 \mathrm{ppm}$ are present in the mixture. Intriguingly, as observed with $\mathbf{3}$, the equilibrium is not reached before $48 \mathrm{~h}$ (Fig. S12 $\dagger$ ). The experiment repeated at pD 2 after addition of $\mathrm{DCl}$ shows that weak additional resonances appeared directly after sample preparation, indicating a rapid hydrolysis, but equilibrium is reached immediately. Analysis of 


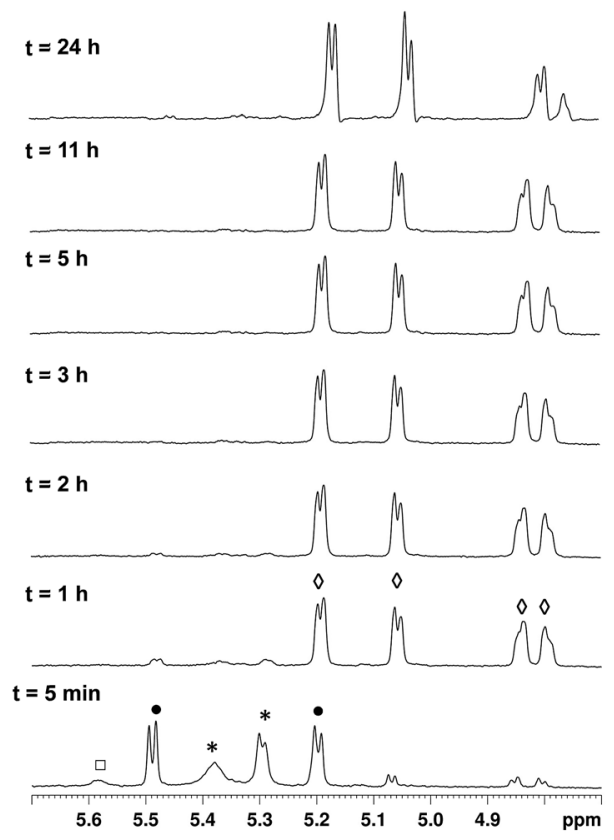

Fig. 4 The $p$-cymene ring proton region of the ${ }^{1} \mathrm{H}$ NMR spectrum of $\left[\left(\eta^{6}-p-\mathrm{MeC}_{6} \mathrm{H}_{4} \mathrm{Pr}^{i}\right)_{2} \mathrm{Ru}_{2}\left(\mu-\mathrm{SCH}_{2}-\mathrm{C}_{6} \mathrm{H}_{4}-p-\mathrm{OMe}\right)_{2} \mathrm{Cl}_{2}\right]$ (4) dissolved in $\mathrm{D}_{2} \mathrm{O} / \mathrm{CD}_{3} \mathrm{CN}$ (ratio $6: 4$ ) recorded between $t=5 \mathrm{~min}$ and $t=24 \mathrm{~h}$ at 37 ${ }^{\circ} \mathrm{C}$ and at pD 7. The labels correspond to $p$-cymene ligands in different species present in solution. The species labeled * corresponds to 4 , the species labeled $\diamond$ is assumed to be the hydroxo-acetonitrile complex $\left[\left(\eta^{6}-p-\mathrm{MeC}_{6} \mathrm{H}_{4} \mathrm{Pr}^{\prime}\right)_{2} \mathrm{Ru}_{2}(\mathrm{OD})\left(\mathrm{CD}_{3} \mathrm{CN}\right)\left(\mu-\mathrm{S}-\mathrm{CH}_{2}-\mathrm{C}_{6} \mathrm{H}_{4}-p-\mathrm{OMe}\right)_{2}\right]^{+}$, while the species labeled with $\bullet$ and $\square$ have not been further characterised.

${ }^{1} \mathrm{H}$ NMR spectra shows that $\mathbf{4}$ is the major species present in the mixture (Fig. S13†).

\subsection{Reactivity of 1-4 with nucleotides and DNA}

In general, arene ruthenium compounds have been shown to bind to DNA model compounds ${ }^{45,46}$ via loss of the chlorido ligands, and loss of the arene was also observed. More importantly, by using a 14-mer oligonucleotide, it has not been possible to identify preferential binding sites, due to the multiple interactions that are available.

Upon addition of $3 \mathrm{eq}$. of dAMP and dGMP, no changes in the NMR spectra are observed for complexes 2 and 3. As an example, the $2 \mathrm{D}^{-1} \mathrm{H}$ DOSY NMR spectrum of the mixture 3: dGMP (ratio $1: 3$ ) recorded after $24 \mathrm{~h}$ is shown in Fig. $\mathrm{S} 14 . \dagger$ In the spectrum two species can be identified: one with the lowest diffusion coefficient being the hydrolysed derivative of $\mathbf{3}$, and the second species being free dGMP. Furthermore, inspection of the $1 \mathrm{D}{ }^{1} \mathrm{H}$ and $2 \mathrm{D}-{ }^{1} \mathrm{H}$ DOSY NMR spectra shows a single $\mathrm{H} 8$ resonance at $\delta 8.22 \mathrm{ppm}$ for dGMP, suggestive of the absence of a coordination of N7 to the Ru atom.

In order to investigate possible reactions with DNA, the complexes 1-4 were incubated at $37^{\circ} \mathrm{C}$ together with the singlestranded DNA 20-mer (CGCGATCGCGGCGCTAGCGC) for $24 \mathrm{~h}$. In analogy with platinum complexes and some other ruthenium compounds, ${ }^{\mathbf{2 0 , 4 2 , 4 7 , 4 8}}$ we assumed that complexes 1-4 could bind to the nucleophilic nitrogen of the nucleotides once they underwent hydrolysis. However, ESI mass spectroscopy spectra recorded in the negative and positive mode (Fig. $\mathrm{S} 15 \dagger$ ) revealed that no adducts are formed between the mono- and dithiolato complexes and the single-stranded DNA 20-mer. Interestingly, we have previously shown that trithiolato complexes are also inert towards nucleotides and DNA. ${ }^{35,36}$ As such, unlike other arene ruthenium complexes, these results suggest that DNA is not a target of thiolato-bridged arene ruthenium complexes and that they exert their cytotoxicity through other mechanisms.

\subsection{Reactivity of 1-4 with aspartic acid, alanine and histidine}

Most of the metallodrugs currently used in antitumoural therapy, such as carboplatin and cisplatin, are administered intravenously and can therefore encounter various reactive biomolecules in the bloodstream. ${ }^{20,47}$ Interactions with peptides and serum proteins can have a pronounced influence on the drug distribution, bioavailability and target or off-target effects. To investigate some of these possible interactions, the neutral amino acid Ala, the acidic amino acid Asp and the basic amino acid His were used. His was also chosen to investigate a possible binding between the imidazole ring and the ruthenium atom, since we and others already showed that imidazole rings strongly and rapidly interact with the ruthenium atom ${ }^{49-54}$ and especially with arene ruthenium complexes. ${ }^{55-58}$

Alanine usually does not react with ruthenium complexes, although a hexacationic arene ruthenium assembly possessing an oxalato linker slowly degrades in the presence of excess of Ala to give mononuclear ruthenium-alanine adducts. ${ }^{53}$ Asp with a coordinating carboxyl side chains is known to form tridentate chelate complexes with ruthenium and other metal centres. ${ }^{54,55,59}$ Upon addition of 3 eq. of Ala and Asp, no changes in the NMR spectra are observed for the four complexes 1-4 (Fig. 5, S16 and S17 $\dagger$ ). As an example, the $2 \mathrm{D}-{ }^{1} \mathrm{H}$ DOSY NMR spectrum of the mixture 1 : Ala (ratio $1: 3$ ) recorded after $24 \mathrm{~h}$ is shown in Fig. 5. In the spectrum four species can be clearly distinguished: two, with the lowest diffusion coefficient, being complex $\mathbf{1}$ and the hydrolysed derivative thereof, the third species being free Ala, and the fourth one acetone.

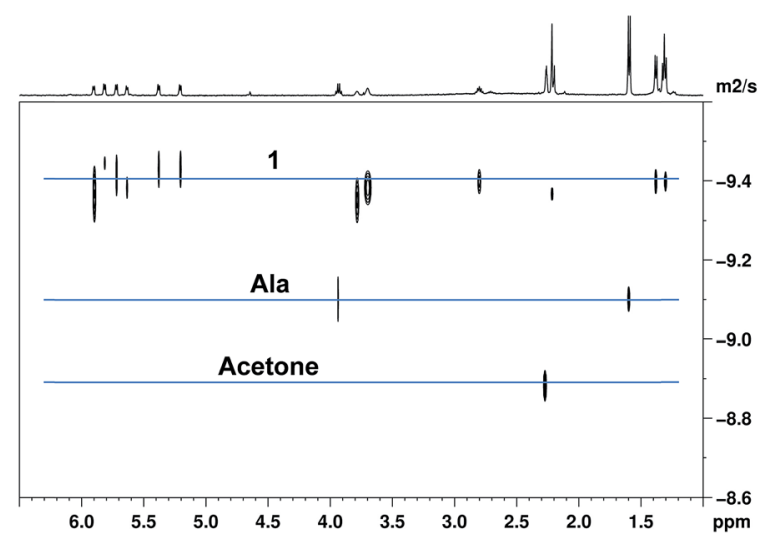

Fig. $52 \mathrm{D}-{ }^{1} \mathrm{H}$ DOSY spectrum of the mixture 1 : Ala (ratio $1: 3$ ) dissolved in $\mathrm{D}_{2} \mathrm{O} /$ acetone- $\mathrm{d}_{6}$ (ratio $7: 3$ ) recorded after $24 \mathrm{~h}$ at $37^{\circ} \mathrm{C}$. 


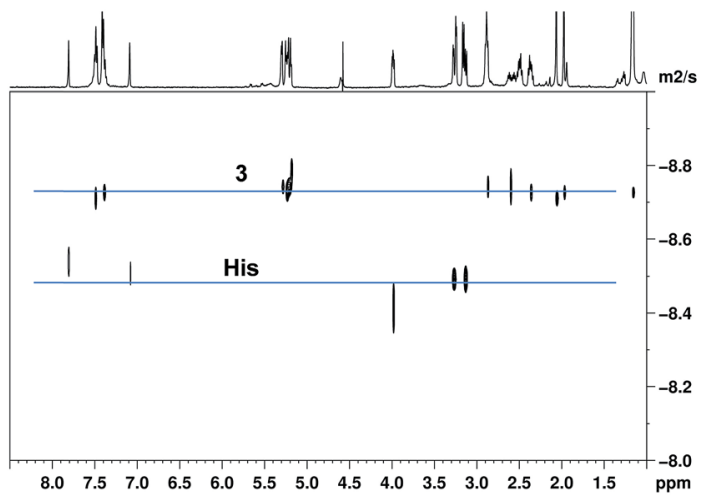

Fig. 6 2D- ${ }^{1} \mathrm{H}$ DOSY spectrum of the mixture 3 : His (ratio $1: 3$ ) dissolved in $\mathrm{D}_{2} \mathrm{O} / \mathrm{CD}_{3} \mathrm{CN}$ (ratio $6: 4$ ) recorded after $24 \mathrm{~h}$ at $37^{\circ} \mathrm{C}$.

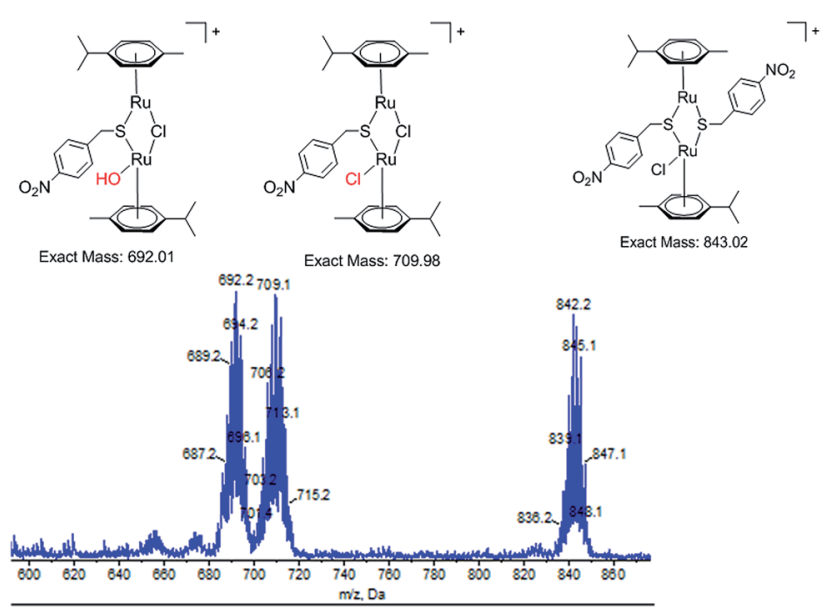

Fig. 7 ESI-MS spectrum of the mixture 2 : His (ratio $1: 3$ ) dissolved in an acetone- $-d_{6} / D_{2} O$ mixture (ratio $3: 7$ ) recorded after $24 \mathrm{~h}$. The structures of the corresponding species are indicated on top of each peak.

Furthermore, inspection of the $1 \mathrm{D}{ }^{1} \mathrm{H}$ and $2 \mathrm{D}-{ }^{1} \mathrm{H}$ DOSY NMR spectra shows a single $\alpha \mathrm{H}$ resonance and a single $\beta_{\mathrm{CH}_{3}}$ resonance for Ala, suggestive of the absence of a coordination of Ala to the $\mathrm{Ru}$ atom.

Upon addition of 3 eq. of His, surprisingly, both NMR and ESI mass spectrometry data strongly suggest that the mono- and dithiolato complexes 1-4 do not react with His (Fig. 6 and S18†). As an example, the $2 \mathrm{D}^{-1} \mathrm{H}$ DOSY spectrum of the mixture $3:$ His (ratio $1: 3$ ) recorded after $24 \mathrm{~h}$ is shown in Fig. 6 . In the spectrum two species can be clearly distinguished: one with the lowest diffusion coefficient being the hydrolysed derivative of complex 3 , the second one being free His. Furthermore, inspection of the 1D ${ }^{1} \mathrm{H}$ and $2 \mathrm{D}-{ }^{1} \mathrm{H}$ DOSY NMR spectra shows for His a single $\alpha \mathrm{H}$ resonance, two $\beta_{\mathrm{CH}_{2}}$ resonances for the two $\beta \mathrm{H}$ diastereotopic protons and especially only two $\mathrm{CH}$ resonances for the imidazole group, suggestive of the absence of a coordination of the imidazole ring of His to the Ru atom. The ESI-MS spectrum of the mixture $2:$ His (ratio $1: 3$ ) recorded after $24 \mathrm{~h}$ shown in Fig. 7 confirms the absence of a coordination of His to the $\mathrm{Ru}$ atom. The groups of peaks observed in the ESI-MS spectrum at $m / z=692.2$, 709.1, and 842.2, respectively, are identical to those observed after the hydrolysis of 2 and correspond the monohydroxo complex $\left[\left(\eta^{6}-p-\mathrm{MeC}_{6} \mathrm{H}_{4} \mathrm{Pr}^{\mathrm{i}}\right)_{2} \mathrm{Ru}_{2}(\mathrm{OH})(\mu-\mathrm{Cl})\left(\mu-\mathrm{SCH}_{2}-p-\mathrm{C}_{6} \mathrm{H}_{4}-\mathrm{NO}_{2}\right)\right]$, complex 2 , and the dithiolato complex $\left[\left(\eta^{6}-p-\mathrm{MeC}_{6} \mathrm{H}_{4} \mathrm{Pr}^{\mathrm{i}}\right)_{2} \mathrm{Ru}_{2} \mathrm{Cl}\left(\mu-\mathrm{SCH}_{2}-p\right.\right.$ $\left.\mathrm{C}_{6} \mathrm{H}_{4}-\mathrm{NO}_{2}\right)_{2}$.

\subsection{Reactivity of 1-4 with cysteine and methionine}

Reactions with the sulphur-containing amino acids Cys and Met appear to play key roles in the biological chemistry of platinum(II), platinum(Iv) and ruthenium(III) anticancer agents, and were shown to form tridentate chelates with arene ruthenium complexes. ${ }^{60}$ The nucleophilicity of methionine is less than that of cysteine, but still it is known to react with electrophilic sites. ${ }^{61,62}$ Upon addition of 4 eq. of Met, NMR data strongly suggest that no reaction takes place between the mono- and dithiolato complexes 1-4 and Met. As an example, $1 \mathrm{D}^{1} \mathrm{H}$ NMR spectra recorded at $t=$ $10 \mathrm{~min}$ and $t=24 \mathrm{~h}$ and the $2 \mathrm{D}^{-1} \mathrm{H}$ DOSY spectrum of the mixture 3 : Met recorded after $48 \mathrm{~h}$ are shown in Fig. S19. $\dagger$ Two species can be identified in the spectrum; one with the lowest diffusion coefficient being the hydrolysed derivative of complex 3, the second one being free Met. Moreover, inspection of the $1 \mathrm{D}^{1} \mathrm{H}$ and $2 \mathrm{D}-{ }^{1} \mathrm{H}$ DOSY NMR spectra shows a single $\alpha \mathrm{H}$ resonance and especially a single $\delta \mathrm{CH}_{3}$ resonance for Met at $\delta 2.15 \mathrm{ppm}$, suggesting that there is no coordination of the methionine sulphur atom to the $\mathrm{Ru}$ atom, because otherwise a characteristic high field shift for the $\delta \mathrm{CH}_{3}$ group would be expected as observed in such complexes. ${ }^{63}$

However, upon addition of 4 eq. of Cys to the complexes 1-4, the spectra reveal that Cys reacts rapidly with the four complexes. In all cases, additional resonances appear immediately after sample preparation, indicating a rapid reaction, and equilibrium is reached rapidly after $2 \mathrm{~h}$. As an example, the $2 \mathrm{D}-{ }^{1} \mathrm{H}$ DOSY NMR spectrum of the mixture 1 : Cys (ratio $1: 3$ ) recorded after $24 \mathrm{~h}$ is shown in Fig. 8. Three species can be clearly identified: the first one with the lowest diffusion coefficient is attributed to an "adduct" containing cysteine and the dithiolato complex, the second species to free Cys, and the third one to acetone. A more in-depth analysis of the ${ }^{1} \mathrm{H}$ - and the $2 \mathrm{D}^{-1} \mathrm{H}$ DOSY NMR spectra shows two distinct $\alpha \mathrm{H}$ resonances (highlighted with a circle) at $\delta 3.7$ and $3.8 \mathrm{ppm}$, respectively, suggesting the presence of two

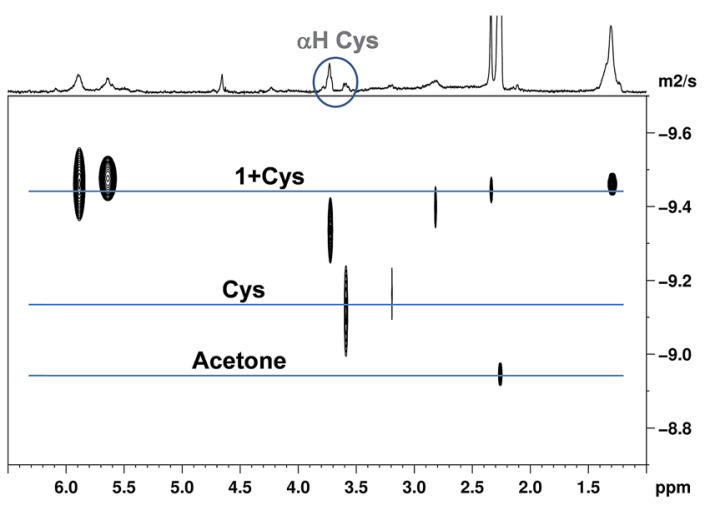

Fig. 8 2D- ${ }^{1} \mathrm{H}$ DOSY spectrum of the mixture 1 : Cys (ratio $1: 2$ ) dissolved in $\mathrm{D}_{2} \mathrm{O}$ /acetone- $\mathrm{d}_{6}$ (ratio $7: 3$ ) recorded after $24 \mathrm{~h}$ at $37^{\circ} \mathrm{C}$. Both $\alpha \mathrm{H}$ resonances of Cys are highlighted with a circle. 
types of cysteine, which is cross-confirmed by their different diffusion coefficient. The $\alpha \mathrm{H}$ resonance at $\delta 3.8 \mathrm{ppm}$ has clearly the same diffusion coefficient than the $p$-cymene proton resonances, although it appears slightly out of alignment because of the close proximity of the intense water resonance at $4.64 \mathrm{ppm}$. The ESI-MS spectrum shown in Fig. 9 exhibits a group of peaks centred at $m / z=887.21$, which corresponds to a diruthenium trithiolato complex containing one cysteinato bridge, $\left[\left(\eta^{6}-p\right.\right.$ $\left.\left.\mathrm{MeC}_{6} \mathrm{H}_{4} \mathrm{Pr}^{\mathrm{i}}\right)_{2} \mathrm{Ru}_{2}\left(\mu-\mathrm{SCH}_{2} \mathrm{CH}\left(\mathrm{NH}_{2}\right) \mathrm{COOH}\right)\left(\mu-\mathrm{S}-m-9-\mathrm{B}_{10} \mathrm{C}_{2} \mathrm{H}_{11}\right)_{2}\right]^{+}$. Similar results were obtained with complexes $\mathbf{2 - 4}$, the formation of the corresponding cysteinato-containing trithiolato complexes as the only species present in the mixtures after $24 \mathrm{~h}$ is confirmed by both NMR and ESI-MS data (Fig. S20-S24†). Interestingly, for both monothiolato complexes $\mathbf{1}$ and $\mathbf{2}$, the cationic trithiolato complex $\left[\left(\eta^{6}-p-\mathrm{MeC}_{6} \mathrm{H}_{4} \mathrm{Pr}^{\mathrm{i}}\right)_{2} \mathrm{Ru}_{2}\left\{\mu-\mathrm{SCH}_{2}-\right.\right.$ $\left.\left.\mathrm{CH}\left(\mathrm{NH}_{2}\right) \mathrm{COOH}\right\}_{2}(\mu-\mathrm{SR})\right]^{+}$containing two bridging cysteinato units, where the bridging sulphur atom of Cys occupies the position of both the second and third bridging thiolato ligands is the unique adduct detected after $24 \mathrm{~h}$ at $37^{\circ} \mathrm{C}$. Similarly, for both dithiolato complexes 3 and $\mathbf{4}$, the cationic trithiolato complex $\left[\left(\eta^{6}-p-\mathrm{MeC}_{6} \mathrm{H}_{4} \mathrm{Pr}^{\mathrm{i}}\right)_{2} \mathrm{Ru}_{2}\left\{\mu-\mathrm{SCH}_{2} \mathrm{CH}\left(\mathrm{NH}_{2}\right) \mathrm{COOH}\right\}(\mu-\mathrm{SR})_{2}\right]^{+}$containing one bridging cysteinato unit, where the bridging sulphur atom of Cys occupies the position of the third bridging thiolato ligand is the unique adduct detected after $24 \mathrm{~h}$ at $37^{\circ} \mathrm{C}$.

The in situ formation of cysteinato-containing trithiolato complexes is somewhat surprising, since our previous attempts to synthesise such complexes by standard methods were unsuccessful; only degradation of the arene ruthenium unit was observed. On the other hand, such complexes are conceivable in the light of the equilibria between the thiolato complexes and the thiol. $^{\mathbf{4 2 , 4 3}}$ For trithiolato complexes, the equilibria between the thiolato complexes and the thiol do not yield cysteinatocontaining trithiolato complexes but catalyse the oxidation of Cys to give cystine. ${ }^{35,43}$ Sadler et al. had observed the formation of dinuclear biphenyl ruthenium complexes with cysteinato bridges from the reaction of $\left[\left(\eta^{6}-\mathrm{C}_{6} \mathrm{H}_{5} \mathrm{Ph}\right) \mathrm{RuCl}(\mathrm{en})\right]^{+}$with $\mathrm{Cys}^{61}$ and the formation of dinuclear $p$-cymene ruthenium trithiolato complexes by reacting $\left[\left(\eta^{6}-p-\mathrm{MeC}_{6} \mathrm{H}_{4} \mathrm{Pr}^{\mathrm{i}}\right)_{2} \mathrm{Ru}_{2} \mathrm{Cl}(\mathrm{en})\right]^{+}$with

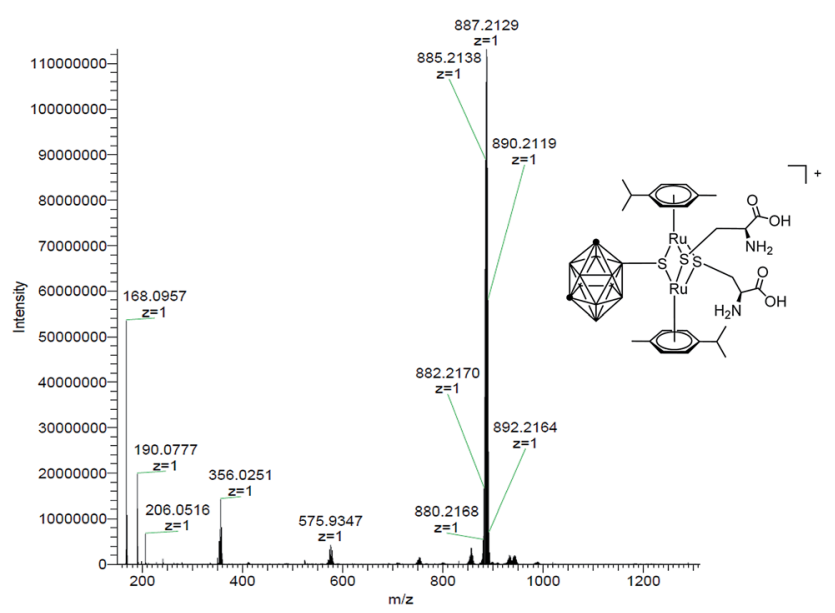

Fig. 9 ESI MS spectrum of the mixture 1 : Cys (ratio $1: 3$ ) dissolved in $\mathrm{H}_{2} \mathrm{O} /$ acetone (ratio $7: 3$ ) recorded after $24 \mathrm{~h}$ in the positive mode.

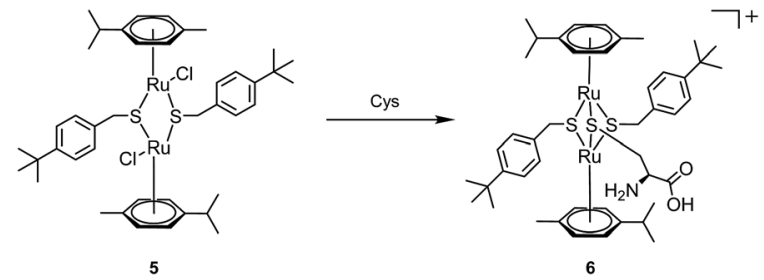

Scheme 2 Synthesis of the cysteinato-containing complex 6, isolated as tetrafluoroborate salt.

2-mercaptobenzanilide in aqueous solution at $\mathrm{pH}=5.3 .^{64} \mathrm{We}$ therefore decided to modify the synthetic conditions and attempted the synthesis and isolation of cysteinato-containing trithiolato complexes by mimicking the conditions of the NMR experiments. The dithiolato complex $\left[\left(\eta^{6}-p-\mathrm{MeC}_{6} \mathrm{H}_{4} \mathrm{Pr}^{\mathrm{i}}\right)_{2} \mathrm{Ru}_{2}(\mu-\right.$ $\mathrm{SCH}_{2} \mathrm{C}_{6} \mathrm{H}_{4}-p$ - $\left.\left.\mathrm{Bu}^{t}\right)_{2} \mathrm{Cl}_{2}\right](5)^{41}$ was dissolved in a small amount of methanol and an aqueous solution of cysteine was added dropwise in large excess. The resulting mixture was stirred at ambient temperature for two days, and a gradual colour change from orange to yellow was observed. The resulting product was unstable at elevated temperature; it also degraded rapidly in purely organic solutions. The product was therefore purified by size exclusion chromatography on Sephadex® LH20 with a $\mathrm{MeOH} / \mathrm{H}_{2} \mathrm{O}(9: 1)$ mixture, evaporated at room temperature and dried in vacuo. Spectroscopic methods and elemental analysis proved the compound to be the tetrafluoroborate salt of the cysteinato-containing trithiolato complex $\left[\left(\eta^{6}-p-\mathrm{MeC}_{6} \mathrm{H}_{4} \mathrm{Pr}^{\mathrm{i}}\right)_{2}\right.$ $\left.\mathrm{Ru}_{2}\left(\mu-\mathrm{SCH}_{2} \mathrm{C}_{6} \mathrm{H}_{4}-p-\mathrm{Bu}^{t}\right)_{2}\left\{\mu-\mathrm{SCH}_{2} \mathrm{CH}\left(\mathrm{NH}_{2}\right) \mathrm{COOH}\right\}\right]^{+}$(6) (Scheme 2).

Because of its low stability, it was not possible to obtain crystals suitable for X-rays analysis. Synthesis of the other cysteinato-containing trithiolato complexes starting from the dithiolato precursors $\mathbf{3}$ and $\mathbf{4}$ was also attempted, but the resulting complexes degraded rapidly and could not be isolated in analytically pure form. The synthesis of the cysteinatocontaining trithiolato complexes starting from the monothiolato precursors $\mathbf{1}$ and $\mathbf{2}$ was not attempted.

To the best of our knowledge, together with the two diruthenium complexes obtained fortuitously by Sadler et al., ${ }^{\mathbf{1}}$ complex 6 is only the second example of a dinuclear arene ruthenium complex containing a cysteinato bridge. Since intracellular biological environment contain millimolar amounts of the tripeptide glutathione ( $\gamma$-Glu-Cys-Gly), such complexes could be of considerable significance inside cells. This is currently being further investigated.

\section{Conclusions}

As reported for many other arene ruthenium complexes, our results show that the presence of chlorido ligands makes monoand dithiolato complexes 1-4 less stable than their trithiolato counterparts, which do not have $\mathrm{Ru}-\mathrm{Cl}$ bonds. The complexes 1-4 hydrolyse readily, though slowly in comparison with other arene ruthenium complexes like RAPTA-C and the RAED family of complexes. Our results also suggest that complexes 1-4 remain relatively inert towards model biomolecules and DNA, 
as adducts were only observed upon addition of Cys. Interestingly, unusual cationic dinuclear trithiolato complexes from which the chlorido ligands had been removed, such as $\left[\left(\eta^{6}-p\right.\right.$ $\left.\left.\mathrm{MeC}_{6} \mathrm{H}_{4} \mathrm{Pr}^{\mathrm{i}}\right)_{2} \mathrm{Ru}_{2}\left\{\mu-\mathrm{SCH}_{2} \mathrm{CH}\left(\mathrm{NH}_{2}\right) \mathrm{COOH}\right\}(\mu-\mathrm{SR})_{2}\right]^{+} \quad$ containing one bridging cysteinato ligand and $\left[\left(\eta^{6}-p-\mathrm{MeC}_{6} \mathrm{H}_{4} \mathrm{Pr}^{\mathrm{i}}\right)_{2} \mathrm{Ru}_{2}\{\mu-\right.$ $\left.\left.\mathrm{SCH}_{2} \mathrm{CH}\left(\mathrm{NH}_{2}\right) \mathrm{COOH}_{2}(\mu-\mathrm{SR})\right]\right]^{+}$containing two bridging cysteinato ligands are observed.

It can be assumed that the propensity of mono- and dithiolato complexes to hydrolyse and to react with sulphurcontaining molecules explains why they are at least an order of magnitude less cytotoxic than trithiolato complexes. As already demonstrated for mononuclear $\mathrm{Ru}(\mathrm{II})$-arene complexes with $O, O$-bound alkoxycarbonylmethyl-3-hydroxy-2 $(1 H)$-pyridones, ${ }^{65}$ our results suggest that there is a negative reactivity-in vitro cytotoxicity relationship for dinuclear thiolato-bridged arene ruthenium complexes: the more reactive mono- and dithiolato complexes are significantly less cytotoxic compared to their trithiolato counterparts. The high stability of dinuclear arene ruthenium trithiolato complexes allows them to accumulate inside the cells of a tumour, ${ }^{40}$ where they can reach their molecular target and deploy their anticancer activity. The monothiolato and dithiolato complexes, on the other hand, can potentially bind to proteins and other molecules containing sulfhydryl groups, which may impede their accumulation in cancer cells in sufficient concentration. However, the prominent examples of the arene ruthenium RAPTA complexes, which are reactive and only exhibit a low activity in vitro, but are very active in vivo, prompt us to further evaluate mono- and dithiolato complexes in in vivo and preclinical models.

\section{Experimental section}

\subsection{Materials and methods}

4.1.1. Chemicals. Analytical grade chemicals obtained from commercial suppliers were used as received. L-alanine, $\mathrm{L}^{-}$ aspartic acid, L-cysteine and L-histidine were purchased from Acros. GSH, Sephadex® LH20 and NaOD and DCl solutions were obtained from Sigma-Aldrich. The single-stranded DNA dodecamer (CGCGATCGCG) ${ }_{2}$ was purchased from Microsynth. Complexes 1-4 and 5 were prepared according to previously published methods. ${ }^{42}$

All reactions were first monitored by $1 \mathrm{D}^{1} \mathrm{H}$ NMR spectroscopy. Two-dimensional homonuclear ${ }^{1} \mathrm{H}^{-1} \mathrm{H}$ and DOSY experiments were performed after $24 \mathrm{~h}$ of incubation at $37{ }^{\circ} \mathrm{C}$. All experiments were carried out in aqueous solutions. The pD values of the solutions were obtained by use of a glass electrode and by addition of 0.41 to the $\mathrm{pH}$ meter reading. ${ }^{\mathbf{6 , 6 7}}$ Oxygen was not excluded from the solutions.

4.1.2. NMR spectroscopy. NMR data were acquired at $37^{\circ} \mathrm{C}$ using a Bruker Avance II $400 \mathrm{MHz}$ NMR spectrometer equipped with a $5 \mathrm{~mm}$ broadband dual channel probehead (Smartprobe ${ }^{\circledR}$ ) and a Bruker Avance II $500 \mathrm{MHz}$ NMR spectrometer equipped with an inverse triple channel $\left({ }^{1} \mathrm{H},{ }^{13} \mathrm{C},{ }^{31} \mathrm{P}\right)$ $z$-gradient $1.7 \mathrm{~mm}$ microprobehead. Both probeheads are equipped with $z$-gradient accessory. One-dimensional ${ }^{1} \mathrm{H}$ NMR data were measured with 256 transients into $32 k$ data points over the width of $12 \mathrm{ppm}$ using a classic presaturation to eliminate the water resonance. A relaxation delay of $2 \mathrm{~s}$ was applied between the transients.

Two-dimensional ${ }^{1} \mathrm{H}-{ }^{1} \mathrm{H}$ COSY data were acquired over a frequency width of $12 \mathrm{ppm}$ in both $F_{2}$ and $F_{1}$ into $2 \mathrm{k}$ complex data points in $F_{2}$ (acquisition time 213 or $170 \mathrm{~ms}$ ) using $128 t_{1}$ increments. 32 transients were recorded per $t_{1}$ increment. The water resonance was suppressed by means of a presaturation routine.

Two-dimensional ${ }^{1} \mathrm{H}$ diffusion-ordered spectroscopy (DOSY) NMR data were acquired with a standard longitudinal encodedecode pulsed-field-gradient stimulated echo sequence containing bipolar gradients. ${ }^{68}$ Experimental parameters were $\Delta=$ $100 \mathrm{~ms}$ (diffusion delay), $\tau=1 \mathrm{~ms}$ (gradient recovery delay) and $T=5 \mathrm{~ms}$ (eddy current recovery delay). For each data set, $4 k$ complex points were collected, and the gradient dimension was sampled by means of 32 experiments in which the gradient strength was linearly increased from 1.0 to $50.8 \mathrm{G} \mathrm{cm}^{-1}$. The gradient duration $\delta / 2$ was adjusted to observe a near-complete signal loss at $50.8 \mathrm{G} \mathrm{cm}^{-1}$. A $2 \mathrm{~s}$ recycle delay was used between scans for the data shown. 32 transients were recorded per experiments. For each data set, the spectral axis was processed with an exponential function (3-5 Hz line broadening), and a Fourier transform was applied to obtain $8 k$ real points. The DOSY reconstruction was realised with $8 k$ complex points in the detection dimension and with 128 points in the diffusion dimension. All NMR data were processed using TopSpin (Version 3.2, Bruker, Switzerland) and Dynamics Center (Version 2.3.1, Bruker, Switzerland).

4.1.3. Electrospray ionisation mass spectrometry. Massspectrometric (MS) analyses were performed with an LTQ Orbitrap XL mass spectrometer (Thermo Fisher Scientific, Bremen, Germany) equipped with a nanoelectrospray ion source. The samples were analysed in the positive or negative ion mode with a voltage of $+700 \mathrm{~V}$ applied to the glass emitter (New Objective, Woburn, MA, USA). The tube lens was at $+150 \mathrm{~V}$ and the transfer capillary was held at $200{ }^{\circ} \mathrm{C}$. Spectra were acquired in Fourier transform mass spectrometry mode over an $\mathrm{m} / \mathrm{z}$ range from 100 to 2000 with a resolution of 100000 at $\mathrm{m} / \mathrm{z} 400$. Calibration of the instrument was performed with ProteoMass LTQ/ FT-Hybrid electrospray ionisation (ESI) positive mode calibration mix (Supelco Analytical, Bellefonte, PA, USA). The Xcalibur software package (Version 2.0.7, Thermo Fisher Scientific) was used for instrument control and data processing.

\subsection{Synthesis of the new compound $\left[\left(\eta^{6}-p\right.\right.$ - $\left.\mathrm{MeC}_{6} \mathrm{H}_{4} \mathrm{Pr}^{\mathrm{i}}\right)_{2} \mathrm{Ru}_{2}\left(\mu-\mathrm{SCH}_{2} \mathrm{C}_{6} \mathrm{H}_{4}-p-\mathrm{Bu}^{t}\right)_{2}\left\{\mu-\mathrm{SCH}_{2} \mathrm{CH}\left(\mathrm{NH}_{2}\right)\right.$ $\mathrm{COOH}\}]\left[\mathrm{BF}_{4}\right]\left([6]\left[\mathrm{BF}_{4}\right]\right)$}

The dithiolato complex $\left[\left(\eta^{6}-p-\mathrm{MeC}_{6} \mathrm{H}_{4} \mathrm{Pr}^{\mathrm{i}}\right)_{2} \mathrm{Ru}_{2} \mathrm{Cl}_{2}\left(\mu-\mathrm{SC}_{6} \mathrm{H}_{4}-p-\right.\right.$ $\left.\mathrm{Bu}^{t}\right)_{2}$ ] (5) (0.056 mmol) was dissolved in $25 \mathrm{~mL}$ of methanol. To this solution, a solution of cysteine (10 eq., $0.560 \mathrm{mmol}$ ) in distilled water $(15 \mathrm{~mL})$ was added dropwise. This mixture was stirred at room temperature for two days. Then 10 equivalents of $\mathrm{NaBF}_{4}$ were then added and the suspension was stirred overnight. The solution obtained after filtration was concentrated by applying a vacuum at room temperature; the light orange solid that precipitated during the evaporation was washed 
thoroughly with water and dissolved again in a $\mathrm{MeOH} / \mathrm{H}_{2} \mathrm{O}$ $(9: 1)$ mixture. The product was isolated by size exclusion chromatography on Sephadex® LH20 from the yellow band. The solvents were evaporated in vacuo, yielding a yellow powder. Yield: mg (95\%), ESI MS (MeOH): $m / z 950.0[\mathrm{M}-\mathrm{Cl}]^{+}, \mathrm{C}_{45} \mathrm{H}_{64}{ }^{-}$ $\mathrm{BF}_{4} \mathrm{NO}_{2} \mathrm{Ru}_{2} \mathrm{~S}_{3} \cdot \mathrm{H}_{2} \mathrm{O}$, calcd: C, 51.27; $\mathrm{H}, 6.31 ; \mathrm{N}, 1.33$, found: $\mathrm{C}$, 51.33; H, 6.15; N, $1.39 ;{ }^{1} \mathrm{H}$ NMR (400 MHz, $\mathrm{CDCl}_{3}$ ): $\delta=7.56-7.41$ $\left[\mathrm{m}, 8 \mathrm{H}, \mathrm{SCH}_{2} \mathrm{C}_{6} H_{4}-p-\mathrm{C}\left(\mathrm{CH}_{3}\right)_{3}\right], 5.57$ [broad, $1 \mathrm{H}, p-\mathrm{CH}_{3} \mathrm{C}_{6} H_{4}-$ $\mathrm{CH}\left(\mathrm{CH}_{3}\right)_{2}$ ], 5.49 [broad, $1 \mathrm{H}, p-\mathrm{CH}_{3} \mathrm{C}_{6} \mathrm{H}_{4} \mathrm{CH}\left(\mathrm{CH}_{3}\right)_{2}$ ], $5.46\left[\mathrm{~d}, J^{3}=\right.$ $\left.5 \mathrm{~Hz}, 1 \mathrm{H}, p-\mathrm{CH}_{3} \mathrm{C}_{6} \mathrm{H}_{4} \mathrm{CH}\left(\mathrm{CH}_{3}\right)_{2}\right], 5.32\left[\mathrm{~d}, J^{3}=5 \mathrm{~Hz}, 1 \mathrm{H}, p-\mathrm{CH}_{3}-\right.$ $\mathrm{C}_{6} \mathrm{H}_{4} \mathrm{CH}\left(\mathrm{CH}_{3}\right)_{2}$ ], 5.22 [broad, $1 \mathrm{H}, p-\mathrm{CH}_{3} \mathrm{C}_{6} \mathrm{H}_{4} \mathrm{CH}\left(\mathrm{CH}_{3}\right)_{2}$ ], 5.17 [broad, $1 \mathrm{H}, p-\mathrm{CH}_{3} \mathrm{C}_{6} \mathrm{H}_{4} \mathrm{CH}\left(\mathrm{CH}_{3}\right)_{2}$ ], 5.02 [broad, $1 \mathrm{H}, p-\mathrm{CH}_{3} \mathrm{C}_{6} \mathrm{H}_{4}$ $\mathrm{CH}\left(\mathrm{CH}_{3}\right)_{2}$ ], 4.95 [broad, $1 \mathrm{H}, p-\mathrm{CH}_{3} \mathrm{C}_{6} \mathrm{H}_{4} \mathrm{CH}\left(\mathrm{CH}_{3}\right)_{2}$ ] $3.77[\mathrm{~m}, 1 \mathrm{H}$, $\left.\mathrm{SCH}_{2} \mathrm{CH}\left(\mathrm{NH}_{2}\right) \mathrm{COOH}\right], 3.73-3.42\left[\mathrm{~m}, 4 \mathrm{H}, \mathrm{SCH}_{2} \mathrm{C}_{6} \mathrm{H}_{5}-p-\mathrm{C}\left(\mathrm{CH}_{3}\right)_{3}\right]$, $3.01\left[\mathrm{~d}, J^{3}=12 \mathrm{~Hz}, 1 \mathrm{H}, \mathrm{SCH} \mathrm{H}_{2} \mathrm{CH}\left(\mathrm{NH}_{2}\right) \mathrm{COOH}\right], 2.75[\mathrm{~m}, 1 \mathrm{H}$, $\left.\mathrm{SCH}_{2} \mathrm{CH}\left(\mathrm{NH}_{2}\right) \mathrm{COOH}\right], 2.23\left[\mathrm{~m}, 2 \mathrm{H}, p-\mathrm{CH}_{3} \mathrm{C}_{6} \mathrm{H}_{4} \mathrm{CH}\left(\mathrm{CH}_{3}\right)_{2}\right], 2.03$ $\left[\mathrm{m}, 6 \mathrm{H}, p-\mathrm{CH}_{3} \mathrm{C}_{6} \mathrm{H}_{4} \mathrm{CH}\left(\mathrm{CH}_{3}\right)_{2}\right], 1.37 \quad\left[\mathrm{~s}, 18 \mathrm{H}, \mathrm{SCH}_{2} \mathrm{C}_{6} \mathrm{H}_{5}-p-\right.$ $\left.\mathrm{C}\left(\mathrm{CH}_{3}\right)_{3}\right]$ 1.14-1.00 [m, 12H, $\left.p-\mathrm{CH}_{3} \mathrm{C}_{6} \mathrm{H}_{4} \mathrm{CH}\left(\mathrm{CH}_{3}\right)_{2}\right] \mathrm{ppm} .{ }^{13} \mathrm{C}$ NMR (100 MHz, $\left.\mathrm{CDCl}_{3}\right): \delta=170.55,151.29,129.01,125.31$, 107.18, 84.36, 83.66, 83.42, 83.22, 82.84, 82.48, 56.73, 48.63, $41.66,40.42,38.97,34.20,31.39,22.94,17.49$ ppm.

\subsection{Stability of 1-4 in aqueous solution}

The stability of complexes 1-4 in aqueous solutions was studied by dissolving $1 \mathrm{mg}$ of the complexes in the mixture of an appropriate deuterated solvent and water $\left(\mathrm{D}_{2} \mathrm{O}\right.$ /acetone- $\mathrm{d}_{6} 7: 3$ for $1, \mathrm{D}_{2} \mathrm{O}$ /acetone- $\mathrm{d}_{6} 6: 4$ for 2 and $\mathrm{D}_{2} \mathrm{O} / \mathrm{CD}_{3} \mathrm{CN} 7: 3$ for 3 and 4). The $\mathrm{pD}$ of the solutions was varied by adding NaOD, phosphate buffer or DCl. The solutions were subsequently transferred to $1.7 \mathrm{~mm}$ NMR tubes and $1 \mathrm{D}^{1} \mathrm{H}-\mathrm{NMR}$ experiments were recorded at $37^{\circ} \mathrm{C}$ after $5 \mathrm{~min}, 30 \mathrm{~min}, 1 \mathrm{~h}, 2 \mathrm{~h}, 3 \mathrm{~h}$, and every two hours until $24 \mathrm{~h}$. An additional spectrum was also systematically recorded after 48 or $72 \mathrm{~h}$.

\subsection{Interactions of 1-4 with amino acids}

$1 \mathrm{mg}$ of the respective complex was dissolved in the appropriate aqueous solution (vide supra). When the hydrolysis reactions had reached a steady state, three to four equivalents of amino acid (Ala, Asp, Cys, Met or His) were added. The solutions were then transferred into NMR tubes and $1 \mathrm{D}{ }^{1} \mathrm{H}$-NMR experiments were measured at $37^{\circ} \mathrm{C}$ after $5 \mathrm{~min}, 30 \mathrm{~min}, 1 \mathrm{~h}, 2 \mathrm{~h}, 3 \mathrm{~h}$ and every two hours until $24 \mathrm{~h}$. An additional spectrum was also systematically recorded after 48 or 72 h. ESI-MS, $2 \mathrm{D}{ }^{1} \mathrm{H}-{ }^{1} \mathrm{H}$ COSY and $2 \mathrm{D}^{1} \mathrm{H}$-DOSY NMR spectra were recorded after the last $1 \mathrm{D}{ }^{1} \mathrm{H}-\mathrm{NMR}$ experiment. Between the measurements, the tubes were stored in the incubator at $37^{\circ} \mathrm{C}$.

\subsection{Interactions of 1-4 with the single stranded DNA dodecamer}

Interaction of complexes with the single-stranded DNA dodecamer (CGCGATCGCGGCGCTAGCGC) was studied by dissolving the complexes in appropriate aqueous solution (vide supra), adding $1 \mathrm{mg}$ of DNA fragment $\left(M_{\mathrm{w}}=6119.2\right)$ and incubating the mixture at $37^{\circ} \mathrm{C}$. MS measurements were performed after $2 \mathrm{~h}$ and $24 \mathrm{~h}$ of incubation.

\section{Acknowledgements}

DS would like to thank Dr Diego Carnevale for his help with the characterization of $[6]\left[\mathrm{BF}_{4}\right]$.

\section{References}

1 B. Rosenberg, L. V. Camp, E. B. Grimley and A. J. Thomson, J. Biol. Chem., 1967, 242, 1347-1352.

2 J. D. Hoeschele, Dalton Trans., 2009, 10648-10650.

3 N. J. Wheate, S. Walker, G. E. Craig and R. Oun, Dalton Trans., 2010, 39, 8113-8127.

4 L. Kelland, Nat. Rev. Cancer, 2007, 7, 573-584.

5 X. Yao, K. Panichpisal, N. Kurtzman and K. Nugent, Am. J. Med. Sci., 2007, 334, 115-124.

6 N. Pabla and Z. Dong, Kidney Int., 2008, 73, 994-1007.

7 P. D. Sánchez-González, F. J. López-Hernández, J. M. LópezNovoa and A. I. Morales, Crit. Rev. Toxicol., 2011, 41, 803821.

8 B. Bhhatarai and P. Gramatica, Chem. Res. Toxicol., 2010, 23, 528-539.

9 R. G. van der Hoop, C. J. Vecht, M. E. L. van der Burg, A. Elderson, W. Boogerd, J. J. Heimans, E. P. Vries, J. C. van Houwelingen, F. G. I. Jennekens, W. H. Gispen and J. P. Neijt, N. Engl. J. Med., 1990, 322, 89-94.

10 L. X. Cubeddu, I. S. Hoffmann, N. T. Fuenmayor and A. L. Finn, N. Engl. J. Med., 1990, 322, 810-816.

11 G. Süss-Fink, Dalton Trans., 2010, 39, 1673-1688.

12 G. Sava, A. Bergamo, S. Zorzet, B. Gava, C. Casarsa, M. Cocchietto, A. Furlani, V. Scarcia, B. Serli, E. Iengo, E. Alessio and G. Mestroni, Eur. J. Cancer, 2002, 38, 427-435.

13 J. M. Rademaker-Lakhai, D. van den Bongard, D. Pluim, J. H. Beijnen and J. H. M. Schellens, Clin. Cancer Res., 2004, 10, 3717-3727.

14 C. G. Hartinger, M. A. Jakupec, S. Zorbas-Seifried, M. Groessl, A. Egger, W. Berger, H. Zorbas, P. J. Dyson and B. K. Keppler, Chem. Biodiversity, 2008, 5, 2140-2155.

15 S. Leijen, S. Burgers, P. Baas, D. Pluim, M. Tibben, E. van Werkhoven, E. Alessio, G. Sava, J. Beijnen and J. M. Schellens, Invest. New Drugs, 2015, 33, 201-214.

16 R. Trondl, P. Heffeter, C. R. Kowol, M. A. Jakupec, W. Berger and B. K. Keppler, Chem. Sci., 2014, 5, 2925-2932.

17 L. D. Dale, J. H. Tocher, T. M. Dyson, D. I. Edwards and D. A. Tocher, Anti-Cancer Drug Des., 1992, 7, 3-14.

18 G. Süss-Fink, J. Organomet. Chem., 2014, 751, 2-19.

19 C. S. Allardyce, P. J. Dyson, D. J. Ellis and S. L. Heath, Chem. Commun., 2001, 1396.

20 R. E. Morris, R. E. Aird, P. del Socorro Murdoch, H. Chen, J. Cummings, N. D. Hughes, S. Parsons, A. Parkin, G. Boyd, D. I. Jodrell and P. J. Sadler, J. Med. Chem., 2001, 44, 3616-3621.

21 B. S. Murray, M. V. Babak, C. G. Hartinger and P. J. Dyson, Coord. Chem. Rev., 2016, 306, 86-114.

22 P. J. Dyson, Chimia, 2007, 61, 698-703.

23 A. Habtemariam, M. Melchart, R. Fernández, S. Parsons, I. D. H. Oswald, A. Parkin, F. P. A. Fabbiani, J. E. Davidson, 
A. Dawson, R. E. Aird, D. I. Jodrell and P. J. Sadler, J. Med. Chem., 2006, 49, 6858-6868.

24 A. Bergamo, A. Masi, A. F. A. Peacock, A. Habtemariam, P. J. Sadler and G. Sava, J. Inorg. Biochem., 2010, 104, 79-86.

25 V. Brabec and O. Novakova, Drug Resist. Updates, 2006, 9, 111-122.

26 S. J. Dougan and P. J. Sadler, Chimia, 2007, 61, 704-715.

27 P. C. A. Bruijnincx and P. J. Sadler, Curr. Opin. Chem. Biol., 2008, 12, 197-206.

28 A. F. A. Peacock and P. J. Sadler, Chem.-Asian J., 2008, 3, 1890-1899.

29 E. S. Antonarakis and A. Emadi, Cancer Chemother. Pharmacol., 2010, 66, 1-9.

30 A. Bergamo, C. Gaiddon, J. H. M. Schellens, J. H. Beijnen and G. Sava, J. Inorg. Biochem., 2012, 106, 90-99.

31 A. A. Nazarov, C. G. Hartinger and P. J. Dyson, J. Organomet. Chem., 2014, 751, 251-260.

32 A. K. Singh, D. S. Pandey, Q. Xu and P. Braunstein, Coord. Chem. Rev., 2014, 270, 31-56.

33 S. Medici, M. Peana, V. M. Nurchi, J. I. Lachowicz, G. Crisponi and M. A. Zoroddu, Coord. Chem. Rev., 2015, 284, 329-350.

34 M. Gras, B. Therrien, G. Süss-Fink, O. Zava and P. J. Dyson, Dalton Trans., 2010, 39, 10305-10313.

35 F. Giannini, G. Süss-Fink and J. Furrer, Inorg. Chem., 2011, 50, 10552-10554.

36 F. Giannini, J. Furrer, A.-F. Ibao, G. Süss-Fink, B. Therrien, O. Zava, M. Baquie, P. J. Dyson and P. Stepnicka, J. Biol. Inorg. Chem., 2012, 17, 951-960.

37 F. Giannini, L. E. H. Paul and J. Furrer, Chimia, 2012, 66, 775-780.

38 F. Giannini, J. Furrer, G. Süss-Fink, C. M. Clavel and P. J. Dyson, J. Organomet. Chem., 2013, 744, 41-48.

39 F. Giannini, L. E. H. Paul, J. Furrer, B. Therrien and G. SüssFink, New J. Chem., 2013, 37, 3503-3511.

40 P. Tomsik, D. Muthna, M. Rezacova, S. Micuda, J. Cmielova, M. Hroch, R. Endlicher, Z. Cervinkova, E. Rudolf, S. Hann, D. Stibal, B. Therrien and G. Süss-Fink, J. Organomet. Chem., 2015, 782, 42-51.

41 A. F. Ibao, M. Gras, B. Therrien, G. Süss-Fink, O. Zava and P. J. Dyson, Eur. J. Inorg. Chem., 2012, 1531-1535.

42 D. Stibal, B. Therrien, F. Giannini, L. E. H. Paul, J. Furrer and G. Süss-Fink, Eur. J. Inorg. Chem., 2014, 5925-5931.

43 J. Furrer and G. Süss-Fink, Coord. Chem. Rev., 2016, 309, 3650.

44 S. J. Dougan, A. Habtemariam, S. E. McHale, S. Parsons and P. J. Sadler, Proc. Natl. Acad. Sci. U. S. A., 2008, 105, 1162811633.

45 A. Dorcier, C. G. Hartinger, R. Scopelliti, R. H. Fish, B. K. Keppler and P. J. Dyson, J. Inorg. Biochem., 2008, 102, 1066-1076.
46 M. Groessl, C. G. Hartinger, P. J. Dyson and B. K. Keppler, J. Inorg. Biochem., 2008, 102, 1060-1065.

47 M. Bacac, A. C. G. Hotze, K. van der Schilden, J. G. Haasnoot, S. Pacor, E. Alessio, G. Sava and J. Reedijk, J. Inorg. Biochem., 2004, 98, 402-412.

48 Y. Jung and S. J. Lippard, Chem. Rev., 2007, 107, 1387-1407.

49 R. F. Borch and M. E. Pleasants, Proc. Natl. Acad. Sci. U. S. A., 1979, 76, 6611-6614.

50 F. Kratz, M. Hartmann, B. Keppler and L. Messori, J. Biol. Chem., 1994, 269, 2581-2588.

51 L. E. H. Paul, B. Therrien and J. Furrer, J. Biol. Inorg. Chem., 2012, 17, 1053-1062.

52 L. E. H. Paul, B. Therrien and J. Furrer, Inorg. Chem., 2012, 51, 1057-1067.

53 L. E. H. Paul, J. Furrer and B. Therrien, J. Organomet. Chem., 2013, 734, 45-52.

54 F. A. Egbewande, L. E. H. Paul, B. Therrien and J. Furrer, Eur. J. Inorg. Chem., 2014, 1174-1184.

55 W. S. Sheldrick, E. Hauck and S. Korn, J. Organomet. Chem., 1994, 467, 283-292.

56 F. Y. Wang, J. Bella, J. A. Parkinson and P. J. Sadler, J. Biol. Inorg. Chem., 2005, 10, 147-155.

57 D. Valensin, P. Anzini, E. Gaggelli, N. Gaggelli, G. Tamasi, R. Cini, C. Gabbiani, E. Michelucci, L. Messori, H. Kozlowski and G. Valensin, Inorg. Chem., 2010, 49, 4720-4722.

58 Z. Bihari, Z. Nagy and P. Buglyo, J. Organomet. Chem., 2015, 782, 82-88.

59 R. Kramer, M. Maurus, R. Bergs, K. Polborn, K. Sunkel, B. Wagner and W. Beck, Chem. Ber., 1993, 126, 1969-1980.

60 W. S. Sheldrick and R. Exner, J. Organomet. Chem., 1990, 386, 375-387.

61 F. Y. Wang, H. M. Chen, J. A. Parkinson, P. D. Murdoch and P. J. Sadler, Inorg. Chem., 2002, 41, 4509-4523.

62 R. H. Wills, A. Habtemariam, A. F. Lopez-Clavijo, M. P. Barrow, P. J. Sadler and P. B. O'Connor, J. Am. Soc. Mass Spectrom., 2014, 25, 662-672.

63 A. Frodl, D. Herebian and W. S. Sheldrick, J. Chem. Soc., Dalton Trans., 2002, 3664-3673.

64 Y. M. Han, Q. Luo, X. Hao, X. C. Li, F. Y. Wang, W. B. Hu, K. Wu, S. Lu and P. J. Sadler, Dalton Trans., 2011, 40, 11519-11529.

65 M. Hanif, H. Henke, S. M. Meier, S. Martic, M. Labib, W. Kandioller, M. A. Jakupec, V. B. Arion, H.-B. Kraatz, B. K. Keppler and C. G. Hartinger, Inorg. Chem., 2010, 49, 7953-7963.

66 P. K. Glasoe and F. A. Long, J. Phys. Chem., 1960, 64, 188-190. 67 K. Mikkelsen and S. O. Nielsen, J. Phys. Chem., 1960, 64, 632637.

68 K. F. Morris and C. S. Johnson, J. Am. Chem. Soc., 1992, 114, 3139-3141. 